\title{
Editorial
}

\section{New Parliaments, New Problems, New Journal}

Growth is a universal phenomenon. It is not only a fundamental, global and constant expectation in economics, but also when it comes to democracy. Although it is a matter of quality, growth can be identified more easily by its quantity: if not the amount of democracy, at least the number of legislatures - together with their members and budgets - is constantly growing. In the past few decades, more and more new parliaments have been created worldwide. By now, almost all independent countries have some form of parliamentary institution. Devolution, federalization, secession, regionalization, integration and internationalization - all these lead to new parliamentary institutions at various levels of government. But does this tendency result in fairer representation, more democracy and better governance? Are these institutions real parliaments or merely legislative organs? And if so, do they matter at all? Our answer - shared by scholars (Russel et al., 2013) as well as practitioners (Johnsson, 2012) - is clearly yes. On the other hand, many scholars, from Schmitt (1923) to Scheppele (2009) emphasise crisis as a permanent feature of parliaments.

At the very least, there is more and more for scholars to discover, analyse, evaluate in the world of parliaments. This expanding universe of parliaments is what brought this journal to life. Our vision is that the history of parliamentarism is still ongoing and there is a lot to say about it. Our mission is to analyse legislatures' actors and activities, including their internal and external relations, from a theoretical, procedural, and practical point of view.

The journal is international, not just in terms of its editors and boards, but also of its authors and readers. Until recently, legislative issues, parliamentary procedure and practice were exclusively the purview of national legislation 
and jurisdiction, and were, therefore, issues primarily for domestic scholarship. However, a kind of parliamentary "ius gentium" or "ius commune" is evolving: Parliamentary activities are increasingly observed by international actors and repeatedly reviewed by international forums. Parliamentary issues are no longer matters for one institution or nation. There are many points of contact between institutions and nations, and learning from one another is certainly possible (e.g., legal transplants, constitution- and state building). Moreover, supranational parliaments (including the European Parliament) are gradually becoming important actors in world politics and policies.

Beyond that, we also aim to break down borders in scholarship. With its intentionally cross-cutting approach, the journal aims to tear down the clearly existing walls between political science and law, scholarship and practice, national and international approaches. We do not promote the creation of parliamentary studies as a new discipline, since it already exists, covering all the different methods, approaches, theories and interpretations that focus on the same, for us, most inspiring phenomenon: the parliament.

Can this cross-cutting approach be successful? Our answer is based on the notion that problems are more important than authors. Problems and phenomena neither respect artificial classifications of scholarly theory, nor the personal ambitions of scholars. It is not possible to write about universal phenomena like equality, freedom or poverty only as sociological, economic or legal problems. Unravelling these issues requires a complex understanding of them. This might not be possible in a single article, but is certainly realistic in a journal, where various different approaches are welcome. We aim to present the macro world of parliamentary issues as an open arena - like the parliament itself. We hope that our contributions will attract both authors and readers from disciplines different from their own. It is essential to burst the bubbles of small scholarly circles and be open to new sources of inspiration. We prefer articles which are not only addressed to a few of the author's peers, but ones which can be understood and appreciated by anyone with a solid knowledge of parliaments. Therefore, out of the two reviewers assigned for scholarly articles, one will be a lawyer, and the other a political scientist. This will hopefully promote the dialogue and cross-readership between the two disciplines.

Besides classic scholarly articles, which are subject to a double-blind peer review, we intend to welcome a variety of genres. In the Report section, we publish research notes and data presentations, which are reviewed like scholarly papers, and which will hopefully inspire further research. The Forum section welcomes opinions rather than scientific findings, may spark future debates - just like politics, parliamentary issues are not black or white, and there is room for a wide range of scholarly opinions, which may not be shared 
by all. These opinion articles are reviewed by one member of the editorial board, only to ensure that the opinion is capable of being argued for or against. Finally, the Parliamentary Procedure and Practice section will give the floor to practitioners - parliamentary officials - to present the aspects of practice and internal operation, from internal institutional methods to parliamentary case-law. These contributions are not subject to standard scholarly peer review, since their authors are not dealing with theory and basic research. The paper selection and quality management is the responsibility of the editor of the section, Christoph Konrath, an official of the Austrian Parliamentary Administration and lecturer at various universities in his country, who is also one of the coordinators of the European Centre for Parliamentary Research and Documentation. The Book review section is also open for all disciplines and authors. We hope that as clearly as parliaments are still needed, so will this new journal with its colourful sections also be needed.

In this first issue, some of the members of the journal team introduce also themselves as authors. This is why the geographic focus of the issue is on Central Europe - in the future we plan to highlight various other regions of the world, like for example the Middle East, East Asia, Africa or South America. In this first issue, most of authors or article topics originate in Central Europe. Firstly, Christoph Konrath presents a cross-cutting issue in a scholarly article: the transformation of political tactics into legal institutions in parliamentary procedures. Next, Flóra Szalai and Boldizsár Szentgáli-Tóth from Hungary will outline European standards of parliamentary publicity, an issue hitherto subject to national jurisdictions. Stephen Bates will explore recent scholarly debates about restructuring parliamentary roles. Zsolt Szabó and Herbert Küpper provide a detailed overview of the legislation on the legislative process in Central and Eastern Europe, focussing on constitutional requirements and procedure. In the Report section, a creative and useful research tool is presented: Olivier Rozenberg (et. al.) introduce two novel indexes measuring legislative activity during the Covid-19 Pandemic. In the Forum section, Zoltán Szente shares his scholarly opinion on the non-parliamentary transformations in the last decade in the Hungarian Parliament.

The Parliamentary Procedure and Practice section presents shorter papers, notes and analyses from parliamentary practitioners. In this issue, recent decisions by the European Court of Human Rights and the Court of Justice of the European Union that shape their views of parliaments and adaptations of parliamentary practice and procedure in the light of the covID-pandemic are the focus. Pieter Caboor discusses the role of the Walloon Parliament in post-election disputes. Rosi Posnik considers the view of the ECJ on the application of data protection regulations in parliaments. Elise 
Uberoi presents insights into the use of remote participation for members of the UK House of Commons in the Covid-crisis, while Sarah Priddy explains how the House of Commons reacted to those challenges in a more general way. When it comes to the digitalisation of parliamentary procedures, it is common to cite the Estonian and Slovenian examples. Ahto Saks and Bojan Verbič present the current status and effective use of digital means in those countries. Finally, Jindřriška Syllová reviews attempts to rationalize the Rules of Procedure in the Czech Parliament from a practitioner's point of view.

In our current issue, three books are presented. Two of them look back on the history of parliaments: an edited volume in honour of Thomas Erskine May by Paul Evans, and a conceptual work analysing parliamentarism from Burke to Weber by William Selinger. The third work is a handbook on a legisprudence issue from Central Europe, edited by Robert Zbiral, describing the ways and means of drafting laws in six countries, supplemented by three topical chapters.

Together with the Associate Editors, the members of the International Editorial Board and the International Advisory Board, I wish all of us, and all friends of parliaments interesting problems, rich volumes with thought-provoking contributions, and interested readers in the future. In the name of all of us, I would like to thank the Brill publishing house for taking the initiative and supporting the launch of this journal. We are grateful also to the Ludovika - University of Public Service, the home institution of the editorial team, for supporting the project. Last but not least, we wish to express our gratitude also to our copyeditor, Stephen Patrick, who duly takes care of the language of the manuscripts. We hope that this journal will set a high standard in the domain of parliamentary studies among the growing number of scholarly journals. We hope that we can contribute to the growth of quality in the field and not only the constant growth in the number of pages printed worldwide.

\author{
Zsolt Szabó \\ Associate professor, Department of Constitutional Law, Károli Gáspár \\ University of the Reformed Church, Budapest, Hungary; senior research \\ fellow, Department of Constitutional and Comparative Public Law, \\ Ludovika - University of Public Service, Budapest, Hungary \\ szabo.zsolt@uni-nke.hu
}




\section{References}

Johnsson, Anders B: Do Parliaments Still Matter? Global Parliamentary Report, IPU, 2012.

Russell, Meg; Gover, Daniel; Wollter, K.: An Elaborate Rubber Stamp? Reassessing executive dominance of the Westminster legislative process', Political Studies Association annual conference, Cardiff, 25-27 March 2013.

Scheppele, Kim Lane: Parliamentary Supplements (or Why Democracies Need More than Parliaments), 89 Boston University Law Review, 795 (2009).

Schmitt, Carl: Crisis of Parliamentary Democracy, 1923, English translation by Ellen Kennedy, 1988, Mit Press. 